\title{
Determination of Beryllium and Selenium in Human Urine and of Selenium in Human Serum by Graphite-Furnace Atomic Absorption Spectrophotometry
}

\author{
Hou-Chuan Wang, Hsien-Wen Peng, and Mao-Sung Kuo ${ }^{\dagger}$ \\ Department of Environmental Science, Tunghai University, Taichung 407, Taiwan, Republic of China
}

\begin{abstract}
For human urine beryllium $(\mathrm{Be})$, each sample $(500 \mu \mathrm{l})$ was diluted $(1+1)$ with Nash reagent (containing $0.2 \%(\mathrm{v} / \mathrm{v})$ acetylacetone and $2.0 \mathrm{M}$ ammonium acetate buffer at $\mathrm{pH} 6.0)$ and then a $20-\mu \mathrm{l}$ volume of Triton $\mathrm{X}-100(0.4 \%$, v/v) aqueous solution was added. An aliquot $(10 \mu \mathrm{l})$ of the diluted urine mixture was introduced into a graphite cuvette and was atomized according to a temperature program. The method detection limit (MDL, $3 \sigma$ ) for Be was $0.37 \mu \mathrm{g} / \mathrm{l}$ in the undiluted urine sample and the calibration graph was linear up to $65.0 \mu \mathrm{g} / \mathrm{l}$. Calibration graphs were prepared by the standard addition method. Accuracies of 98.6-102\% were obtained when testing standard reference material (SRM 2670) freeze dried human urine samples. Precision (relative standard deviation, RSD) for urine Be was $\leq 2.3 \%$ (withinrun, $n=5$ ) and was $\leq 3.0 \%$ (between-run, $n=3$ ). For human urine and serum selenium (Se), samples $(100 \mu \mathrm{l})$ were diluted with $\mathrm{HNO}_{3}(0.2 \%$, v/v) to make a $(1+1)$ dilution for urine analysis or a $(1+4)$ dilution for serum analysis. An additional aliquot $(10 \mu \mathrm{l})$ of Triton X-100 $(0.1 \%$, v/v) was added to each $200 \mu \mathrm{l}$ of $(1+1)$ diluted urine (or $20 \mu \mathrm{l}$ of the Triton X-100 was added to each $500 \mu \mathrm{l}$ of $(1+4)$ diluted serum) sample. After the diluted sample mixture $(10 \mu \mathrm{l})$ was introduced into a graphite cuvette, the corresponding chemical modifier $\left(10 \mu \mathrm{l}\right.$, containing $\mathrm{Ni}^{2+}+\mathrm{Pd}+\mathrm{NH}_{4} \mathrm{NO}_{3}$ in $\mathrm{HNO}_{3}$ $(0.2 \%, \mathrm{v} / \mathrm{v}))$ was added to it and the mixture was atomized. The MDL $(3 \sigma)$ for Se in urine and in serum was 4.4 and 21.4 $\mu \mathrm{g} / \mathrm{l}$ in undiluted sample, respectively, and the calibration graphs were linear up to 150 and $400 \mu \mathrm{g} / \mathrm{l}$. Accuracies of urine Se were $98.9-99.4 \%$ by testing SRM 2670 (NIST) urine standards with RSD (between-run, $n=3$ ) within $2.9 \%$; and that of serum Se was $97.2 \%$ when testing a certified second-generation human serum (No. 29, \#664) with RSD (between-run, $n=3$ ) of $1.4 \%$. The proposed method can be applied easily, directly, and accurately to the measurement of Be and Se in real samples (including six urine Se and four serum Se from patients of Blackfoot Disease in Taiwan).
\end{abstract}

(Received October 6, 2000; Accepted January 29, 2001)

Beryllium (Be) and its metal alloys (such as $\mathrm{Cu}, \mathrm{Al}, \mathrm{Mg}, \mathrm{Ni}$ ) have been widely used for electrical equipment, electronic instrumentation, structural components for aircraft, missiles, satellites, and nuclear reactors. ${ }^{1-3}$ Be and its compounds are very toxic and may cause lung disease (berylliosis), ${ }^{1-3}$ inhibit alkaline phosphatase, hepatic adenosine triphosphatase, ${ }^{4}$ and DNA synthesis. ${ }^{5}$ The levels of $\mathrm{Be}$ in human urine for normal healthy persons are very low $(0.04-0.76 \mu \mathrm{g} / \mathrm{l}),{ }^{6}$ but a concentration greater than $20 \mu \mathrm{g} / \mathrm{l}$ is considered to be toxic. ${ }^{7}$

Graphite-furnace atomic absorption spectrometry (GFAAS), ${ }^{8,9}$ or electrothermal atomic absorption spectrometry (ETAAS), with a suitable chemical modifier (such as, lutetium, ammonium 12-molybdophosphate, ${ }^{8}$ palladium, ${ }^{9}$ magnesium nitrate and Triton $\mathrm{X}-100^{10}$ ) has been commonly used for the measurement of $\mathrm{Be}$ in urine samples. In another method, a urine sample $(25 \mathrm{ml})$ was digested with acids, followed by fluorometric detection. ${ }^{11}$

The first part of this paper describes how the concentration $(0.37-65.0 \mu \mathrm{g} / \mathrm{l})$ of $\mathrm{Be}$ in undiluted urine samples can be directly determined by GFAAS after the urine sample was diluted $(1+1)$ with a Nash reagent containing acetylacetone $(0.2 \%, \mathrm{v} / \mathrm{v})$ in ammonium acetate buffer of $\mathrm{pH}$ 6.0. The accuracy was tested with standard reference materials (SRM 2670 freeze-dried human urine)

† To whom correspondence should be addressed.
Selenium ( $\mathrm{Se})$ is an essential trace element in living organisms ${ }^{2,12}$ because Se acts as a cofactor in the glutathione peroxidase of cell membrane and is important in cellular detoxification of peroxides. ${ }^{13}$ From the intake of daily food and drinking water, Se or its salts accumulates in kidneys,,$^{12}$ liver, ${ }^{12,13}$ plasma, ${ }^{14}$ blood, ${ }^{14}$ and serum, ${ }^{13-19}$ or is excreted in the urine. ${ }^{15,19-28}$ The normal levels of urine Se are in the range of $10-100 \mu \mathrm{g} / 1,{ }^{7}$ but a concentration greater than $400 \mu \mathrm{g} / \mathrm{l}$ is considered toxic. $^{7}$ Several normal levels of serum $\mathrm{Se}$ are reported as follows: $80-270 \mu \mathrm{g} / \mathrm{l}$ from the Clinical Guide Laboratory Test; ${ }^{7} 29-139 \mu \mathrm{g} / \mathrm{l}$ from a review ${ }^{17}$ by collecting the results of healthy subjects from Germany, France, Italy, Ireland, Switzerland, Hungary, Greece, USA, and Spain; $5-160 \mu \mathrm{g} / \mathrm{l}$ from the Glasgow Royal Infirmary Trace Element Unit. ${ }^{29}$ Smaller concentrations of Se may cause diseases, such as anemia, ${ }^{30}$ heart disease, ${ }^{13-17,28}$ or cancer; ${ }^{13,28}$ whereas large concentrations of Se cause changes in diastolic blood pressure, ${ }^{30}$ higher uric acid, ${ }^{30}$ or gastrointestinal troubles. ${ }^{17}$

Several techniques used for the determination of Se in human urine and serum are inductively coupled plasma-mass spectrometry (ICP-MS) after diluting samples, ${ }^{15,28}$ HPLC-ICPMS for urine Se speciation ${ }^{23-25}$ and hydride-generation atomic absorption spectrometry (HGAAS) after digesting samples with acids; ${ }^{13,20}$ flow-injection HGAAS; ${ }^{14,21}$ HPLC-HGAAS; ${ }^{22}$ fluorometric detection; ${ }^{19}$ constant current stripping analysis; ${ }^{26}$ and GFAAS (or ETAAS); ${ }^{16-18}$ or GFAAS after microwave 
Table 1 Suitable temperature programs for (a) beryllium and (b) selenium in (1+1) diluted urine sample and (c) selenium in (1+4) diluted serum sample by GFAAS

\begin{tabular}{|c|c|c|c|c|c|c|}
\hline \multirow{2}{*}{$\begin{array}{c}\text { Sample } \\
\text { Step }\end{array}$} & \multicolumn{2}{|c|}{ (a) Be in urine } & \multicolumn{2}{|c|}{ (b) Se in urine } & \multicolumn{2}{|c|}{ (c) Se in serum } \\
\hline & Temperature $/{ }^{\circ} \mathrm{C}$ & Duration/s & Temperature $/{ }^{\circ} \mathrm{C}$ & Duration/s & Temperature $/{ }^{\circ} \mathrm{C}$ & Duration/s \\
\hline Drying & $80-120$ & 30 & $80-120$ & 50 & $80-120$ & 60 \\
\hline \multirow[t]{4}{*}{ Ashing } & $600-1200$ & 45 & $120-400$ & 90 & $120-400$ & 60 \\
\hline & & & $400-1000$ & 60 & $1000-1200$ & 10 \\
\hline & & & $1000-1200$ & 10 & $1200-1200$ & 60 \\
\hline & & & $1300-1300$ & 15 & & \\
\hline Atomization ${ }^{\mathrm{a}}$ & $2800-2800$ & 4 & $2800-2800$ & 4 & $2800-2800$ & 4 \\
\hline Cleaning & $2800-2800$ & 5 & $2800-2800$ & 5 & $2800-2800$ & 5 \\
\hline
\end{tabular}

a. Flow was stopped during atomization step.

digestion. ${ }^{27}$

The second part of this paper describes how the contents of Se in urine $(4.4-150 \mu \mathrm{g} / \mathrm{l})$ and serum $(21-400 \mu \mathrm{g} / \mathrm{l})$ samples can be directly measured by GFAAS after $(1+1)$ and $(1+4)$ dilution with $\mathrm{HNO}_{3}(0.2 \%$, v/v), respectively, and using appropriate amounts of $\mathrm{Ni}^{2+}+\mathrm{Pd}+\mathrm{NH}_{4} \mathrm{NO}_{3}$ as the chemical modifier. The accuracies were tested with certified reference materials (SRM 2670 freeze-dried human urine and a second-generation biological human serum). The proposed method can be applied to the analysis of real samples (including six urine and four serum samples from the patients in Blackfoot Disease Treatment Center in Taiwan).

\section{Experimental}

\section{Apparatus}

A Hitachi Z-8000 graphite-furnace atomic absorption spectrophotometer, equipped with a Zeeman background corrector, was used for the atomic absorption measurement of Be at $234.9 \mathrm{~nm}$ (or of Se at $196.0 \mathrm{~nm}$ ) with a slit width of 1.3 nm. Hollow cathode lamps of Be and Se (Hitachi Co., Japan) were operated at $10 \mathrm{~mA}$ and $12.5 \mathrm{~mA}$, respectively. Uncoated graphite tube cuvettes (No. 180-7400, Hitachi Co., Japan) were purchased.

\section{Reagents and solutions}

All chemicals used were of analytical grade or better. Nitric acid (double distilled, Seastar Co., Canada) was used to prepare $0.2 \% \mathrm{HNO}_{3}(\mathrm{v} / \mathrm{v})$ with pure water (Barnstead NANOpure system). Stock standard solutions of $1000 \mathrm{mg} / \mathrm{l}$ for Be $\left(\mathrm{Be}\left(\mathrm{NO}_{3}\right)_{2} \cdot 4 \mathrm{H}_{2} \mathrm{O}\right.$ in $\left.0.5 \mathrm{M} \mathrm{HNO}_{3}\right)$ and for $\mathrm{Se}\left(\mathrm{SeO}_{2}\right.$ in $0.5 \mathrm{M}$ $\mathrm{HNO}_{3}$ ) were purchased from Merck (Germany). Working standard solutions of $\mathrm{Be}$ and Se were prepared daily by diluting $10.0 \mathrm{mg} / \mathrm{l}$ of the corresponding standard solutions with $0.2 \%$ $\mathrm{HNO}_{3}(\mathrm{v} / \mathrm{v})$. Sodium chloride was superpure grade (Merck) and Triton X-100 was from Sigma (USA). A Nash reagent containing $150 \mathrm{~g}$ ammonium acetate (Merck), $3.0 \mathrm{ml}$ glacial acetic acid (99.99\%, Aldrich), and $2.0 \mathrm{ml}$ acetylacetone (Merck) per liter of aqueous solution (i.e., 2.0 M ammonium acetate buffer at $\mathrm{pH} 6.0$ together with $0.2 \%$ acetylacetone $(\mathrm{v} / \mathrm{v}))$ was prepared weekly. Palladium nitrate $\left[\mathrm{Pd}\left(\mathrm{NO}_{3}\right)_{2} \cdot x \mathrm{H}_{2} \mathrm{O}\right]$, nickel nitrate hexahydrate $(99.999 \%)$, and ammonium nitrate (99.99\%) were from Aldrich and were used to prepare chemical modifiers for Se.

Standard reference samples of freeze-dried human urine (SRM 2670, NIST, USA) contain a normal level $\leq 0.5 \mu \mathrm{g} / 1$ of Be and $30 \pm 8 \mu \mathrm{g} / \mathrm{l}$ of Se; and an elevated level of $33 \mu \mathrm{g} / \mathrm{l}$ of Be and $460 \pm 30 \mu \mathrm{g} / \mathrm{l}$ of Se after reconstitution in $20.0 \mathrm{ml}$ of pure water.
The following two certified freeze-dried human serums were purchased. Seronorm Trace Elements Batch No. 116 (Nycomed Pharma As, Norway) contains $(100 \pm 6) \mu \mathrm{g} / \mathrm{l}$ of Se after reconstituion in $3.00 \mathrm{ml}$ of pure water. A second-generation biological reference material (Department of Internal Medicine, University Hospital, Ghent, Belgium) ${ }^{31}$ contains $1.05 \pm 0.05$ $\mu \mathrm{g} / \mathrm{g}$ of Se (dry weight) after reconstitution in $1.00 \mathrm{ml}$ of pure water.

\section{Samples of human urine and serum}

For Be test, two urine samples (\#1, of about 1.21 and \#2, of about $1.5 \mathrm{l}$ ) were obtained by collecting urine for $24 \mathrm{~h}$ from two normal persons in cleaned polyethylene bottles and were refrigerated at $-20^{\circ} \mathrm{C}$ while not in use. For Se test, one urine sample (\#3, of about 1.81 ) was obtained by collecting urine for $24 \mathrm{~h}$ from a normal person. Another six urine samples (\#4 to \#9) collected at one time (10 $\mathrm{ml}$ for urine Se measurements and another $10 \mathrm{ml}$ for creatinine analysis, containing 36, 78, 88, 66, 48 , and $38 \mathrm{mg} / 100 \mathrm{ml}$ of creatinine, respectively) and four serum samples (\#1 to \#4) were obtained from patients in the Blackfoot Disease Treatment Center (Provincial Hsing-Yin Hospital, Pei-Men, Tainan County, Taiwan) through the help of Dr. Ming-Yuh Wang.

\section{Analytical procedure for Be in urine}

Since the concentrations of $\mathrm{Be}$ in the urine of two normal persons [about $0.042 \mu \mathrm{g} / \mathrm{l}$, obtained from standard addition method $(0-40 \mu \mathrm{l}$ of $200 \mu \mathrm{g} / \mathrm{l}$ of $\mathrm{Be})]$ were below the method detection limit $(0.37 \mu \mathrm{g} / \mathrm{l}$ in undiluted urine), one of them (urine sample \#1) was used as the matrix of urine and calibration graphs were prepared by the following standard additions method. Five hundred microliters of urine sample \#1 were pipetted into vials $(10 \mathrm{ml})$ and various amounts of standard solutions of $\mathrm{Be}(0-100 \mu \mathrm{l}$ of $200 \mu \mathrm{g} / \mathrm{l}$ or $80 \mu \mathrm{l}$ of $400 \mu \mathrm{g} / \mathrm{l}$ in $\left.\mathrm{HNO}_{3}(0.2 \%, \mathrm{v} / \mathrm{v})\right)$ and Nash reagent $(400-500 \mu \mathrm{l})$ were added to make a $(1+1)$ dilution. In order to decrease the sample viscosity and to dispense the sample more evenly in the graphite cuvette, an additional aliquot of $20 \mu \mathrm{l}$ Triton X-100 (0.4\%, v/v) was added to each $1000 \mu \mathrm{l}$ of $(1+1)$ diluted sample. $\mathrm{A} \mathrm{NaCl}$ $(0.9 \%, w / v)$ solution ${ }^{7}$ was correspondingly diluted and was used as a simulated blank for urine. A portion $(10 \mu \mathrm{l})$ of the $(1+1)$ diluted urine sample mixture, or the blank solution, was introduced into a graphite cuvette and atomized according to a temperature program (Table 1(a)). Peak heights in absorbance were used for quantitative analysis. Real urine samples were diluted (1+1) with Nash reagent before adding Triton X-100 and then analyzing by the procedure described above. 


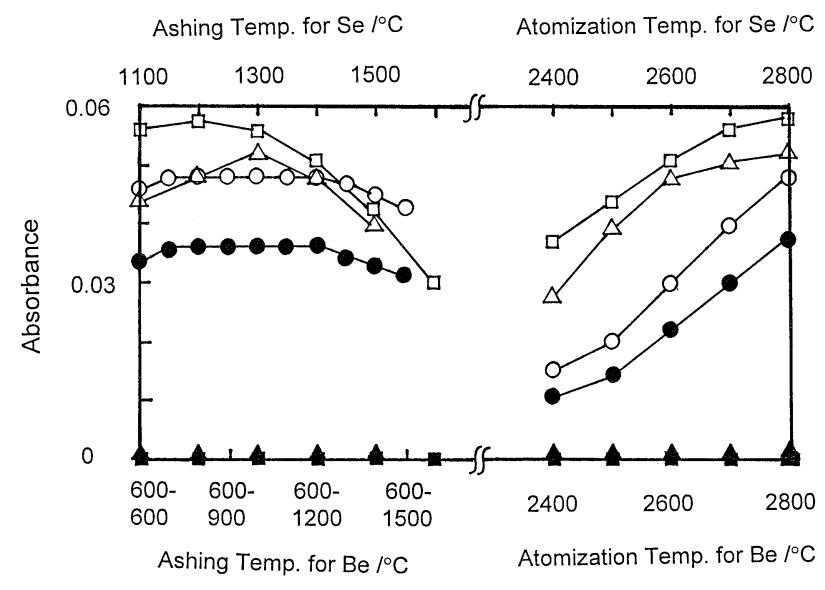

Fig. 1 Effect of ashing and atomization temperature on absorbance with (open symbols) and without (solid symbols) chemical modifier for $40 \mathrm{pg}$ Be in $10 \mu \mathrm{l}$ of (1+1) diluted urine (o); $0.62 \mathrm{ng}$ Se in $10 \mu \mathrm{l}$ of $(1+1)$ diluted urine $(\triangle)$; and $0.96 \mathrm{ng}$ Se in $10 \mu \mathrm{l}$ of $(1+4)$ diluted serum $(\square)$, respectively.

\section{Analytical procedure for Se in urine and in serum}

Calibration graphs were prepared by pipetting $100 \mu \mathrm{l}$ of SRM 2670 normal level human urine (or Seronorm Batch No. 116 human serum) reconstituted solution into vials $(10 \mathrm{ml})$. Various amounts of $\mathrm{HNO}_{3}(0.2 \%, \mathrm{v} / \mathrm{v})$ and a standard solution of Se $\left(100 \mu \mathrm{g} / \mathrm{l}\right.$ in $\left.\mathrm{HNO}_{3}(0.2 \%, \mathrm{v} / \mathrm{v})\right)$ were added to make a $(1+1)$ dilution for urine, or a $(1+4)$ dilution for serum sample, together with standard additions. Real samples of human urine (\#3 to \#9) were diluted $(1+1)$, or human serum (\#1 to \#4) were diluted $(1+4)$, with $\mathrm{HNO}_{3}(0.2 \%$, v/v), respectively. An $\mathrm{NaCl}(0.9 \%$, $\mathrm{w} / \mathrm{v})$ solution $^{7}$ was correspondingly diluted and was used as a simulated blank for urine and serum. An additional aliquot of $10 \mu \mathrm{l}$ of Triton X-100 $(0.1 \%, \mathrm{v} / \mathrm{v})$ was added to each $200 \mu \mathrm{l}$ of $(1+1)$ diluted urine sample, or $20 \mu \mathrm{l}$ of Triton X-100 $(0.1 \%, \mathrm{v} / \mathrm{v})$ was added to each $500 \mu \mathrm{l}$ of $(1+4)$ diluted serum sample. After the diluted sample mixture, or the blank solution $(10 \mu \mathrm{l})$, was introduced into a graphite cuvette, the corresponding chemical modifier [10 $\mu \mathrm{l}$, containing $\mathrm{Ni}^{2+}(150 \mu \mathrm{g})+\mathrm{NH}_{4} \mathrm{NO}_{3}(100 \mu \mathrm{g})+$ $\mathrm{Pd}(5.5 \mu \mathrm{g})$ in $\mathrm{HNO}_{3}(0.2 \%, \mathrm{v} / \mathrm{v})$ for urine and $\mathrm{Ni}^{2+}(25 \mu \mathrm{g})+$ $\mathrm{NH}_{4} \mathrm{NO}_{3}(100 \mu \mathrm{g})+\mathrm{Pd}(3.7 \mu \mathrm{g})$ in $\mathrm{HNO}_{3}(0.2 \%, \mathrm{v} / \mathrm{v})$ for serum] was added to it and the mixture was atomized according to a temperature program (Table 1(b) or 1(c)).

\section{Results and Discussion}

\section{For Be in urine}

The effect of ramping ashing temperatures (from $600-600$ to $600-1500^{\circ} \mathrm{C}$ for $\left.45 \mathrm{~s}\right)$ and atomization temperatures $(2400$ $2800^{\circ} \mathrm{C}$ for $4 \mathrm{~s}$ ) on absorbance with and without the chemical modifier was tested with $40 \mathrm{pg}$ Be in $10 \mu \mathrm{l}$ of $(1+1)$ diluted urine sample. The results (Fig. 1) indicate that the sensitivity of absorbance for $\mathrm{Be}$ in urine is enhanced by a factor of 1.3 in the presence of the chemical modifier. When a ramping ashing temperature is higher than $600-1200^{\circ} \mathrm{C}$ for $45 \mathrm{~s}$, the absorbance begins to decrease; and when atomization temperature increases from 2400 to $2800^{\circ} \mathrm{C}$ for $4 \mathrm{~s}$, the absorbance increases. Hence, suitable ramping ashing $\left(600-1200^{\circ} \mathrm{C}\right)$ and atomization $\left(2800^{\circ} \mathrm{C}\right)$ temperatures were obtained as tabulated in Table 1(a).

The effect of the $\mathrm{pH}(3.0-7.0)$ of Nash reagent (containing $2.0 \mathrm{M}$ ammonium acetate buffer and $0.2 \%(\mathrm{v} / \mathrm{v})$ acetylacetone) on the absorbance of Be was tested with $40 \mathrm{pg}$ Be in $10 \mu \mathrm{l}$ of
$(1+1)$ diluted urine sample. The result indicates that the absorbances are large when the $\mathrm{pH}$ is in the range of $4.0-6.5$. Since the formation of beryllium acetylacetonate ${ }^{32}$ is favored in the $\mathrm{pH}$ range of $5.5-6.0,32$ the acetate buffer $\mathrm{pH}$ of 6.0 was selected. Similarly, amounts of acetylacetone $(0-60 \mu \mathrm{l})$ and ammonium acetate buffer $(0.20-2.0 \mathrm{mmol}$ of $\mathrm{pH} \mathrm{6.0)}$ in the Nash reagent were varied; the results indicate that the absorbances are relatively large when Nash reagent contains $10-20 \mu \mathrm{l}$ of acetylacetone and $0.80-2.0 \mathrm{mmol}$ ammonium acetate buffer. Hence, $20 \mu \mathrm{l}$ of acetylacetone and $1.0 \mathrm{mmol}$ of ammonium acetate buffer in the Nash reagent (i.e., $2.0 \mathrm{M}$ ammonium acetate buffer and $0.20 \%(\mathrm{v} / \mathrm{v})$ acetylacetone) were used in this study.

Following the proposed method, the MDL for Be was determined as the concentration corresponding to three times the standard deviation of twelve replicates using $10 \mu \mathrm{l}$ of the $(1+1)$ diluted urine mixture at the lowest concentration (1.0 $\mu \mathrm{g} / \mathrm{l})$ of the calibration graph. The MDL $(3 \sigma)$ of human urine Be from the mean of seven determinations was found to be 0.18 $\pm 0.01 \mu \mathrm{g} / \mathrm{l}$ in the $(1+1)$ diluted sample. This corresponds to $0.37 \mu \mathrm{g} / \mathrm{l}$ (or $3.7 \mathrm{pg}$ ) in the undiluted urine sample. The limit of detection (LOD, $3 \sigma$ ) values of $\mathrm{Be}$ reported and chemical modifiers used are compared as shown in Table 2. The MDL value of Be obtained in this work is higher than $0.019 \mathrm{pg},{ }^{6}$ but is comparable to others ${ }^{8,10,11}$ reported elsewhere. A typical calibration graph for Be from standard addition method is $y=$ $9.27 \times 10^{-3} x+2.11 \times 10^{-3}$ and is linear up to $32.0 \mu \mathrm{g} / \mathrm{l}$ in $(1+1)$ dilution (or $0.37-65.0 \mu \mathrm{g} / \mathrm{l}$ in undiluted urine samples) with a correlation coefficient of 0.9995 .

The accuracies of the proposed method were checked by testing with $4.95,8.25$, and $16.5 \mu \mathrm{g} / \mathrm{l}$ of $\mathrm{Be}$ in $(1+1)$ dilution prepared from the certified normal level and elevated level of SRM 2670 reconstituted urine samples. The results of $98.6-$ $102 \%$ are listed in Table 3(a). The precision (RSD) for urine Be in within-run measurements $(n=5)$ is $\leq 2.3 \%$ and in betweenrun $(n=3)$ measurements is $\leq 3.0 \%$.

Concentrations of $\mathrm{Be}$ in real urine samples (\#1 and \#2) from two normal persons were measured by the proposed method and were found to be N.D. $(<0.18 \mu \mathrm{g} / \mathrm{L}$ of $\mathrm{Be}$ in $(1+1)$ dilution $)$. After spiking 4.00 and $8.00 \mathrm{ng}$ of Merck Be in $500 \mu \mathrm{L}$ of urine samples, respectively, the average recoveries from triplicates were $98.3-103 \%$ with RSD within $2.5 \%$. The proposed method uses acetylacetone to react with $\mathrm{Be}(\mathrm{II})$ in the presence of ammonium acetate buffer of $\mathrm{pH} 6.0$ to form a chelate of beryllium acetylacetonate, ${ }^{32,33}$ which enhances the sensitivity for Be. The proposed method can be applied easily and accurately to the measurement of $\mathrm{Be}(0.37-65.0 \mu \mathrm{g} / \mathrm{l})$ in urine samples. The linear range covers the toxic level of $>20 \mu \mathrm{g} / \mathrm{l}$ of Be in the urine. $^{7}$

\section{For Se in urine}

The effect of final ashing temperatures $\left(1100-1500^{\circ} \mathrm{C}\right.$ for 15 s) and atomization temperatures $\left(2400-2800^{\circ} \mathrm{C}\right.$ for $\left.4 \mathrm{~s}\right)$ on absorbance with and without the chemical modifier was tested with $0.62 \mathrm{ng}$ of Se in $10 \mu \mathrm{l}$ of $(1+1)$ diluted urine sample. The results (Fig. 1) indicate that without the chemical modifier, Se is lost completely during pyrolysis. In the presence of the chemical modifier during ashing, absorbance increases from 1100 to $1300^{\circ} \mathrm{C}$ for $15 \mathrm{~s}$ and decreases after $1400^{\circ} \mathrm{C}$. During atomization, the absorbance increases as temperature increases from 2400 to $2800^{\circ} \mathrm{C}$ for $4 \mathrm{~s}$. Hence, suitable ashing $\left(1300^{\circ} \mathrm{C}\right)$ and atomization $\left(2800^{\circ} \mathrm{C}\right)$ temperatures were obtained as tabulated in Table 1(b).

The effect of chemical modifiers $[10 \mu$, containing various amounts of $\mathrm{Ni}^{2+}(0-175 \mu \mathrm{g}), \mathrm{Pd}(0-7.4 \mu \mathrm{g})$, and $\mathrm{NH}_{4} \mathrm{NO}_{3}(0-$ 
Table 2 Comparative values of limit of detection (L.O.D.) and characteristic mass ( $m_{\mathrm{o}}$ ) for urine Be, urine Se, and serum Se using different chemical modifiers

\begin{tabular}{|c|c|c|c|c|c|}
\hline Element & Chemical modifier & L.O.D. $(3 \sigma)^{\mathrm{a}} / \mu \mathrm{g} \mathrm{1^{-1 }}$ & $m_{\mathrm{o}}^{\mathrm{b}} / \mathrm{pg}$ & Condition & Ref. No. \\
\hline urine $\mathrm{Be}$ & $\operatorname{acac}(0.2 \%) / \mathrm{NH}_{4} \mathrm{OAc}$ buffer $(2 \mathrm{M})$ & $0.37(3.7 \mathrm{pg})$ & 1.9 & (1+1) dilution; $10 \mu \mathrm{l}$ injected & this work \\
\hline urine $\mathrm{Be}$ & $\mathrm{Lu}(6 \mu \mathrm{g})$ & $(0.019 \mathrm{pg})$ & 0.45 & without dilution; $20 \mu \mathrm{l}$ injected & 6 \\
\hline urine $\mathrm{Be}$ & ascorbic acid/ $\left(\mathrm{NH}_{4}\right)_{3} \mathrm{PMo}_{12} \mathrm{O}_{40}$ & $(1.0 \mathrm{pg})$ & 0.44 & $(1+1)$ dilution; $20 \mu l$ injected & 8 \\
\hline urine $\mathrm{Be}$ & $\mathrm{Mg}\left(\mathrm{NO}_{3}\right)_{2} / \mathrm{HNO}_{3} /$ Triton $\mathrm{X}-100$ & 0.20 & 1.7 & $(1+3)$ dilution; $20 \mu$ l injected & 10 \\
\hline urine $\mathrm{Be}$ & Aniline- $N$-salicylidene & 0.5 & & $25 \mathrm{ml}$ urine digested & 11 \\
\hline urine $\mathrm{Se}$ & $\begin{array}{l}\mathrm{Ni}^{2+}(150 \mu \mathrm{g}) / \mathrm{Pd}(5.5 \mu \mathrm{g}) / \\
\mathrm{NH}_{4} \mathrm{NO}_{3}(100 \mu \mathrm{g})\end{array}$ & $4.4 \quad(44 \mathrm{pg})$ & 104 & $(1+1)$ dilution; $10 \mu \mathrm{l}$ injected & this work \\
\hline urine $\mathrm{Se}$ & & $0.5 \quad(975 \mathrm{pg})$ & & $6.5 \mathrm{ml}$ urine digested; $1.95 \mathrm{ml}$ used & 26 \\
\hline urine $\mathrm{Se}(\mathrm{IV})$ & acetic acid $(5 \%)$ & 1.8 & & $(1+1)$ dilution; using Int. Std. ${ }^{c}$ & 28 \\
\hline urine $\mathrm{Se}$ & $\mathrm{Ni}^{2+}(20 \mu \mathrm{g})$ & 1.2 & & $\begin{array}{l}5 \mathrm{ml} \text { urine digested, diluted to } 25 \mathrm{ml} \text {, } \\
20 \mu \mathrm{l} \text { injected }\end{array}$ & 27 \\
\hline \multirow[t]{2}{*}{ urine $\mathrm{Se}$} & ethanol $(5 \%) / \mathrm{HNO}_{3} /$ Triton $\mathrm{X}-100 / \mathrm{Y}$ & 2.7 & & $(1+10)$ dilution; using ${ }^{78}$ Se Int. Std. & 15 \\
\hline & $\mathrm{Ni}^{2+}(75 \mu \mathrm{g}) / \mathrm{HNO}_{3} /$ Triton $\mathrm{X}-100$ & 14.5 & & $(1+4)$ dilution; $20 \mu$ injected & 15 \\
\hline urine $\mathrm{Se}$ & $\mathrm{NaBH}_{4}(0.5 \%) / \mathrm{NaOH}(0.16 \%)$ & 3 & & HPLC, digestion, $100 \mu$ l injected & 22 \\
\hline urine $\mathrm{Se}$ & $\mathrm{NaBH}_{4}(3 \%) / \mathrm{NaOH}(1 \%)$ & 4.73 & & standard addition method & 20 \\
\hline urine $\mathrm{Se}$ & $\mathrm{NH}_{4} \mathrm{OAc}$ buffer/methanol & $5(26-32 \mathrm{pg})$ & & $(1+1)$ dilution; $50 \mu$ injected & 23 \\
\hline urine Se & $\mathrm{Ir}$ & 6 & & $\begin{array}{l}1 \mathrm{ml} \text { urine digested, diluted to } 50 \mathrm{ml} \text {, } \\
500 \mu \mathrm{l} \text { injected to FI }\end{array}$ & 21 \\
\hline urine $\mathrm{Se}(\mathrm{IV})$ & $\mathrm{HNO}_{3}(1 \%)$ & $(40 \mathrm{pg})$ & & $(1+4)$ dilution; $200 \mu \mathrm{l}$ injected & 24 \\
\hline urine $\mathrm{Se}(\mathrm{IV})$ & & $(50 \mathrm{pg})$ & & $(1+1.5)$ dilution; $100 \mu l$ injected & 25 \\
\hline serum Se & $\begin{array}{l}\mathrm{Ni}^{2+}(25 \mu \mathrm{g}) / \mathrm{Pd}(3.7 \mu \mathrm{g}) / \\
\mathrm{NH}_{4} \mathrm{NO}_{3}(100 \mu \mathrm{g})\end{array}$ & $21.4(214 \mathrm{pg})$ & 364 & $(1+4)$ dilution; $10 \mu$ linjected & this work \\
\hline serum Se & ethanol $(5 \%) / \mathrm{HNO}_{3} /$ Triton $\mathrm{X}-100 / \mathrm{Y}$ & 2.7 & & $(1+10)$ dilution; using ${ }^{78}$ Se Int. Std. & 15 \\
\hline serum Se & $\mathrm{Ni}^{2+}(75 \mu \mathrm{g}) / \mathrm{HNO}_{3} /$ Triton $\mathrm{X}-100$ & $14.5(290 \mathrm{pg})$ & & $(1+4)$ dilution; $20 \mu$ l injected & 15 \\
\hline serum Se & $\mathrm{Pd}(5 \mu \mathrm{g}) / \mathrm{Mg}\left(\mathrm{NO}_{3}\right)_{2}(15 \mu \mathrm{g})$ & $14.5(290 \mathrm{pg})$ & & $(1+4)$ dilution; $20 \mu \mathrm{l}$ injected & 16 \\
\hline serum Se & $\mathrm{NaBH}_{4} / \mathrm{NaOH}$ & $31 \quad(6200 \mathrm{pg})$ & & $\begin{array}{l}0.5 \mathrm{ml} \text { serum digested, }(1+19) \text { dilution, } \\
200 \mu \mathrm{l} \text { injected }\end{array}$ & 13 \\
\hline \multirow[t]{6}{*}{ serum Se } & $\mathrm{Ir}$ & 12 (180 pg) & & $(1+4)$ dilution; $15 \mu l$ injected & 18 \\
\hline & $\mathrm{Pd}(2.5 \mu \mathrm{g})$ & $13 \quad(195 \mathrm{pg})$ & & & \\
\hline & $\mathrm{Pd} / \mathrm{Mg}\left(\mathrm{NO}_{3}\right)_{2}$ & 13 (195 pg) & & & \\
\hline & $\mathrm{Ni}^{2+}(2.5-5.0 \mu \mathrm{g})$ & $14 \quad(210 \mathrm{pg})$ & & & \\
\hline & $\mathrm{Ir} / \mathrm{Mg}\left(\mathrm{NO}_{3}\right)_{2}$ & $16 \quad(240 \mathrm{pg})$ & & & \\
\hline & $\mathrm{Cu}^{2+}$ & $16.5(248 \mathrm{pg})$ & & & \\
\hline
\end{tabular}

a. Concentration in the undiluted sample. b. The mass (pg)/0.0044 absorbance unit. c. Using ${ }^{76} \mathrm{Se},{ }^{77} \mathrm{Se},{ }^{78} \mathrm{Se}$, and ${ }^{82} \mathrm{Se}$ internal standards.

$200 \mu \mathrm{g})$ ] on absorbance is shown in Fig. 2 by testing with 0.62 ng Se using the temperature program listed in Table 1(b). When $10 \mu \mathrm{l}$ of chemical modifier contains $5.5 \mu \mathrm{g}$ of $\mathrm{Pd}$ and $100 \mu \mathrm{g}$ of $\mathrm{NH}_{4} \mathrm{NO}_{3}$, the absorbance increases rapidly as $\mathrm{Ni}^{2+}$ increases from 0 to $150 \mu \mathrm{g}$ and becomes stable after $150 \mu \mathrm{g}$. $\mathrm{Ni}^{2+}$ may form the stable complex $(\mathrm{NiSe})^{34}$ with $\mathrm{Se}$ and eliminate the interference from phosphorous containing molecules (PO and $\mathrm{P}_{2}$ ) in urine and serum..$^{35}$ Therefore, the sensitivity ${ }^{36}$ for $\mathrm{Se}$ in the urine sample is enhanced. When the chemical modifier contains $150 \mu \mathrm{g} \mathrm{Ni}{ }^{2+}$ and $100 \mu \mathrm{g} \mathrm{NH}_{4} \mathrm{NO}_{3}$, the absorbance slightly increases as Pd increases from 0 to $5.5 \mu \mathrm{g}$ and then decreases after $5.5 \mu \mathrm{g}$. Pd may form stable complexes ( $\operatorname{SePd}^{37,38}$ and/or $\mathrm{SePd}_{2}{ }^{34,38}$ ) with $\mathrm{Se}$ and eliminate the phosphorousmolecular interference in urine and serum. ${ }^{35}$ Therefore, the sensitivity for Se is enhanced. When the chemical modifier contains $150 \mu \mathrm{g} \mathrm{Ni}{ }^{2+}$ and $5.5 \mu \mathrm{g} \mathrm{Pd}$, the absorbance slightly increases as $\mathrm{NH}_{4} \mathrm{NO}_{3}$ increases from 0 to $100 \mu \mathrm{g}$ and then decreases after $100 \mu \mathrm{g}$. $\mathrm{NH}_{4} \mathrm{NO}_{3}$ may volatilize $\mathrm{NaCl}^{36}$ in the urine and serum samples ${ }^{7}$ and enhance the sensitivity for Se. Hence, a chemical modifier $(10 \mu \mathrm{l})$ containing $\mathrm{Ni}^{2+}(150 \mu \mathrm{g})+$ $\mathrm{Pd}(5.5 \mu \mathrm{g})+\mathrm{NH}_{4} \mathrm{NO}_{3}(100 \mu \mathrm{g})$ in $\mathrm{HNO}_{3}(0.2 \%$, v/v) was used for human urine samples in this work. The results of LOD for urine and serum Se obtained in this work (Table 2) are comparable to those using $\mathrm{Ni}^{2+},{ }^{15,18,27} \mathrm{Pd},{ }^{18} \mathrm{Pd} / \mathrm{Mg}\left(\mathrm{NO}_{3}\right)_{2},{ }^{16,18}$ $\mathrm{Cu},{ }^{18} \mathrm{Ir},{ }^{18,21} \mathrm{Ir} / \mathrm{Mg}\left(\mathrm{NO}_{3}\right)_{2}{ }^{18}$ for urine and/or serum Se.

Following the proposed method, the MDL was determined as the concentration corresponding to three times the standard deviation of twelve replicates using $10 \mu \mathrm{l}$ of the $(1+1)$ diluted urine at $14.3 \mu \mathrm{g} / \mathrm{l}$ of Se prepared from the normal level of SRM 2670 urine sample. The MDL $(3 \sigma)$ of human urine Se from the mean of four determinations was found to be $(2.1 \pm 0.2) \mu \mathrm{g} / \mathrm{l}$ in the $(1+1)$ diluted sample. This corresponds to $4.4 \mu \mathrm{g} / \mathrm{l}$ (or 44 $\mathrm{pg}$ ) of Se in the undiluted urine sample. The LOD values of urine Se reported and chemical modifiers used are compared as shown in Table 2. The MDL value obtained in this work is comparable to those (using ICP-MS, ${ }^{15,28}$ stripping analysis, ${ }^{26}$ HGAAS, ${ }^{20}$ HPLC-HGAAS, ${ }^{22}$ HPLC-HG-ICP-MS, ${ }^{23}$ FI-HGETAAS, ${ }^{21}$ or, HPLC-ICP-MS ${ }^{24,25}$ ) reported elsewhere. A typical calibration graph for urine Se from standard addition method is $y=5.90 \times 10^{-4} x+4.32 \times 10^{-4}$ and is linear up to 71.4 $\mu \mathrm{g} / \mathrm{l}$ in $(1+1)$ dilution (or $150 \mu \mathrm{g} / \mathrm{l}$ of $\mathrm{Se}$ in undiluted urine sample) with a correlation coefficient of 0.9990.

The accuracy of the proposed method was checked by testing 34.8 and $55.2 \mu \mathrm{g} / \mathrm{l}$ of $\mathrm{Se}$ in $(1+1)$ diluted samples prepared from the elevated and normal levels of SRM 2670 urine standards with $\mathrm{HNO}_{3}(0.2 \%$, v/v). The results of $(98.9-99.4) \%$ were obtained from the mean of three determinations with RSD (between-run) within 2.9\%, as tabulated in Table 2(b). Real urine samples (\#3 to \#9) were measured by using the proposed method and were found to contain $24.6 \pm 0.8,23.7 \pm 0.2,55.9 \pm$ $2.3,16.0 \pm 0.4,33.8 \pm 0.6,18.1 \pm 0.6$, and $13.2 \pm 0.6 \mu \mathrm{g} / \mathrm{l}$ of Se, respectively, in undiluted samples from triplicates. The RSD 
Table 3 Accuracy tests for (a) Be and (b) Se in urine and (c) Se in serum

\begin{tabular}{|c|c|c|}
\hline \multicolumn{2}{|c|}{ Conc. of $\mathrm{Be}(\mathrm{II})$ in urine $/ \mu \mathrm{g} \mathrm{1^{-1 }}$} & \multirow{2}{*}{ Accuracy $^{\mathrm{b}}, \%$} \\
\hline Prepared $^{\mathrm{a}}$ & Found $^{b}$ & \\
\hline 4.95 & $4.88 \pm 0.03$ & $98.6 \pm 0.6$ \\
\hline 8.25 & $8.42 \pm 0.08$ & $102 \pm 1$ \\
\hline 16.5 & $16.7 \pm 0.5$ & $101 \pm 3$ \\
\hline
\end{tabular}

\begin{tabular}{|c|c|c|c|}
\hline \multirow[t]{2}{*}{ (b) } & \multicolumn{2}{|c|}{ Conc. of Se in urine/ $\mu \mathrm{g}^{-1}$} & \multirow{2}{*}{ Accuracy $^{\mathrm{b}}, \%$} \\
\hline & Prepared $^{\mathrm{a}}$ & Found $^{\mathrm{b}}$ & \\
\hline & 34.8 & $34.6 \pm 1.0$ & $99.4 \pm 2.9$ \\
\hline & 55.2 & $54.6 \pm 0.6$ & $98.9 \pm 1.1$ \\
\hline
\end{tabular}

\begin{tabular}{|c|c|c|}
\hline \multicolumn{2}{|c|}{ Conc. of Se in serum $/ \mu \mathrm{g}^{-1}$} & \multirow{2}{*}{ Accuracy $^{\mathrm{b}}, \%$} \\
\hline Prepared $^{c}$ & Found $^{\mathrm{b}}$ & \\
\hline 28.5 & $27.7 \pm 0.4$ & $97.2 \pm 1.4$ \\
\hline
\end{tabular}

a. At $(1+1)$ dilution prepared from certified normal level and elevated level of SRM 2670 reconstituted urine samples.

b. Mean of three determinations with standard deviation.

c. At $(1+4)$ dilution prepared from the second-generation human serum (No. 29, \#664, Dept. of Internal Medicine, University Hospital, Ghent, Belgium).

(within-run, $n=3$ ) was within $4.5 \%$. The concentrations of $\mathrm{Se}$ measured in urine samples from one normal person and six patients in Blackfoot Disease Treatment Center were in the normal range $(10-100 \mu g / 1){ }^{7}$ The urinary Se concentrations obtained from six Blackfoot Disease patients are comparable to those $(2.2-57.1 \mu \mathrm{g} / \mathrm{l})$ reported by Horng et al. ${ }^{27}$ After spiking Merck Se standard solutions $(14.3-28.6 \mu \mathrm{g} / \mathrm{l})$ to three urine samples (\#3, \#4, and \#5) in $(1+1)$ dilution, the average recoveries from triplicates were $98.9-102 \%$ with $\mathrm{RSD}$ within $4.6 \%$. It is concluded that the proposed method provides an easy, accurate, and direct technique for the measurement of $\mathrm{Se}$ in $(1+1)$ diluted urine samples using $\mathrm{Ni}^{2+}(150 \mu \mathrm{g})+\mathrm{Pd}(5.5 \mu \mathrm{g})$ $+\mathrm{NH}_{4} \mathrm{NO}_{3}(100 \mu \mathrm{g})$ as a chemical modifier.

\section{For Se in serum}

The effect of final ashing temperatures $\left(1100-1600^{\circ} \mathrm{C}\right.$ for 60 s) and atomization temperatures $\left(2400-2800^{\circ} \mathrm{C}\right.$ for $\left.4 \mathrm{~s}\right)$ on absorbance with and without the chemical modifier was tested with $0.96 \mathrm{ng}$ of Se in $10 \mu \mathrm{l}$ of $(1+4)$ diluted serum sample (prepared from Seronorm Trace Elements Batch No. 116). The results (Fig. 1) indicate that without the chemical modifier, Se is lost completely during pyrolysis. In the presence of the chemical modifier, absorbance increases from $1100-1200^{\circ} \mathrm{C}$ for $60 \mathrm{~s}$ and decreases after $1300^{\circ} \mathrm{C}$ during ashing. During atomization, the absorbance increases as temperature increases from 2400 to $2800^{\circ} \mathrm{C}$ for $4 \mathrm{~s}$. Hence, suitable ashing $\left(1200^{\circ} \mathrm{C}\right)$ and atomization $\left(2800^{\circ} \mathrm{C}\right)$ temperatures were obtained as tabulated in Table 1(c).

Similarly, the effect of chemical modifiers $(10 \mu \mathrm{l}$, containing various amounts of $\mathrm{Ni}^{2+}(0-150 \mu \mathrm{g}), \mathrm{Pd}(0-14.8 \mu \mathrm{g})$, and $\left.\mathrm{NH}_{4} \mathrm{NO}_{3}(0-300 \mu \mathrm{g})\right)$ on absorbance was compared by testing with $0.96 \mathrm{ng}$ of serum Se using the temperature program (Table 1 (c)). Similar to Fig. 2, a chemical modifier containing $\mathrm{Ni}^{2+}(25$ $\mu \mathrm{g})+\mathrm{Pd}(3.7 \mu \mathrm{g})+\mathrm{NH}_{4} \mathrm{NO}_{3}(100 \mu \mathrm{g})$ was selected for human serum in this work.

The MDL of serum Se was determined similarly to that described in urine Se by using $10 \mu$ of $(1+4)$ diluted serum

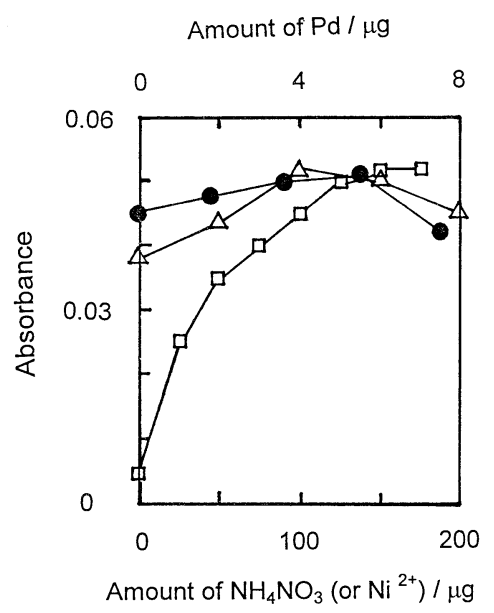

Fig. 2 Effect of amount of each constituent in $10 \mu \mathrm{l}$ chemical modifier on atomization absorbance for $0.62 \mathrm{ng} \mathrm{Se}$ in $(1+1)$ diluted urine. [ $\bullet$, varying $\mathrm{Pd}$ while keeping $\mathrm{Ni}^{2+}(150 \mu \mathrm{g})$ and $\mathrm{NH}_{4} \mathrm{NO}_{3}(100$ $\mu \mathrm{g}) ; \Delta$, varying $\mathrm{NH}_{4} \mathrm{NO}_{3}$ while keeping $\mathrm{Ni}^{2+}(150 \mu \mathrm{g})$ and $\mathrm{Pd}(5.5$ $\mu \mathrm{g}) ; \square$, varying $\mathrm{Ni}^{2+}$ whlie keeping $\mathrm{Pd}(5.5 \mu \mathrm{g})$ and $\mathrm{NH}_{4} \mathrm{NO}_{3}(100$ $\mu \mathrm{g})]$.

sample at $19.2 \mu \mathrm{g} / \mathrm{l}$ of Se prepared from Seronorm Batch No. 116 human serum. The MDL $(3 \sigma)$ value for serum Se was found to be $(4.11 \pm 0.27) \mu \mathrm{g} / \mathrm{l}$ in $(1+4)$ dilution from the mean of three determinations. This corresponds to $21.4 \mu \mathrm{g} / \mathrm{l}$ (or 214 $\mathrm{pg}$ ) of Se in the undiluted serum. The LOD values of serum $\mathrm{Se}$ reported and chemical modifiers used are compared as shown in Table 2. The MDL value obtained in this work is higher than $2.7 \mu \mathrm{g} / 1$ by ICP-MS, ${ }^{15}$ but is comparable to others (HGAAS, ${ }^{13}$ and ETAAS using $\mathrm{Pd},{ }^{18} \mathrm{Ni}^{2+},{ }^{18} \mathrm{Pd} / \mathrm{Mg}\left(\mathrm{NO}_{3}\right)_{2},{ }^{16,18} \mathrm{Ir},{ }^{18} \mathrm{Ir} /$ $\mathrm{Mg}\left(\mathrm{NO}_{3}\right)_{2}$, or $\mathrm{Cu}^{2+}, 18$ as a chemical modifier) reported elsewhere.

Following the proposed method, a typical calibration graph for serum Se is $y=5.22 \times 10^{-4} x-8.30 \times 10^{-4}$ and is linear up to $76.9 \mu \mathrm{g} / \mathrm{l}$ in $(1+4)$ dilution (or $400 \mu \mathrm{g} / \mathrm{l}$ in undiluted serum sample) with a correlation coefficient of 0.9995 . The accuracy of the proposed method was checked by testing $28.5 \mu \mathrm{g} / \mathrm{l}$ of $\mathrm{Se}$ prepared from the second-generation human serum (No. 29, \#664) at $(1+4)$ dilution. The results of $(97.2 \pm 1.4) \%$ were obtained from the mean of three determinations as listed in Table 3(c). Real serum samples (\#1 to \#4) were analyzed by using the proposed method and were found to contain $234.5 \pm$ $5.2,248.6 \pm 5.2,143.0 \pm 3.1$, and $98.8 \pm 0.5 \mu \mathrm{g} / \mathrm{l}$ of $\mathrm{Se}$ in undiluted samples, respectively, from triplicates. The RSD (within-run, $n=3$ ) is within $2.2 \%$. The concentrations of $\mathrm{Se}$ measured in four serum samples from these four patients in Blackfoot Disease Treatment Center are in the normal range of $80-270 \mu \mathrm{g} / \mathrm{l}$ suggested by the Clinical Guide Laboratory Test. However, the two higher serum Se values above exceed the range of values reported for healthy subjects by others (29-139 $\mu \mathrm{g} / \mathrm{l}^{17}$ and 5-160 $\left.\mu \mathrm{g} / \mathrm{l}\right) .^{29}$ After spiking Merck Se standard solutions (9.60 and $19.2 \mu \mathrm{g} / \mathrm{l})$ to serum sample \#4 at $(1+4)$ dilution, the average recoveries from triplicates were $98.4-$ $102 \%$ with RSD within $2.9 \%$. Thus, the proposed method can be applied easily, directly, and accurately to the measurement of Se in $(1+4)$ diluted serum samples using $\mathrm{Ni}^{2+}(25 \mu \mathrm{g})+\mathrm{Pd}(3.7$ $\mu \mathrm{g})+\mathrm{NH}_{4} \mathrm{NO}_{3}(100 \mu \mathrm{g})$ as a chemical modifier. 


\section{Acknowledgements}

The authors thank both the National Science Council of the Republic of China for financial support (NSC 88-2113-M-029002 and NSC 83-0421-M-029-008-Z) and Dr. M. Y. Wang for his help to obtain real urine and serum samples from the patients in Blackfoot Disease Treatment Center.

\section{References}

1. T. Okutani, Y. Tsuruta, and A. Sakuragawa, Anal. Chem., 1993, 65, 1273.

2. S. E. Manahan, "Environmental Chemistry", 7th ed., 2000, Lewis Publishers, Boca Raton, 180, 189, 317, 318.

3. USEPA, Technology Transfer Network, 107-02-8, "Beryllium and Compounds", 1998, Office of Air Quality Planning \& Standards, Research Triangle Park, North Carolina.

4. S. J. S. Flora, S. Mathur, and R. Mathur, Toxicology, 1995, 95, 167.

5. H. P. Witschi, Biochem. J., 1970, 120, 623.

6. J. L. Burguera, M. Burguera, C. Rondon, and P. Carrero, Spectrochim. Acta, 1999, 54B, 1743.

7. N. W. Tietz (ed.), "Clinical Guide to Laboratory Test", 1983, W. B. Saunders Company, Pennsylvania, 76, 110 $112,440$.

8. X. Q. Shan, Z. Yian, and Z. M. Ni, Anal. Chim. Acta, 1989, $217,271$.

9. W. M. Yang and Z. M. Ni, Spectrochim. Acta, 1994, 49B, 1067.

10. D. C. Paschal and G. G. Bailey, At. Spectrosc., 1986, 7, 1.

11. F. Capitan, A. Navalon, and J. L. Vilchez, Quim. Anal., [Barcelona], 1990, 9, 81.

12. O. A. Levander, in "Modern Nutrition in Health and Disease", ed. M. E. Shils and V. R. Young, 7th ed., 1988, Lea \& Febiger, Philadelphia, 263 - 267.

13. D. Q. Hao, G. H. Xie, Y. M. Zhang, and G. J. Tian, Talanta, 1996, 43, 595.

14. K. McLaughlin, D. Dadgar, and M. R. Smyth, Analyst [London], 1990, 115, 275.

15. D. E. Nixon, T. P. Moyer, and M. F. Burritt, Spectrochim. Acta, 1999, 54B, 931.

16. W. K. Chen, C. C. Yen, B. L. Wei, C. C. Hu, J. J. Yu, C.
Chung, and S. C. Kuo, Spectrochim. Acta, 1998, 53B, 131.

17. R. Sabe, R. Rubio, and L. Garcia-Beltran, Anal. Chim. Acta, 2000, 419, 121.

18. R. Sabe, R. Rubio, and L. Garcia-Beltran, Anal. Chim. Acta, 1999, 398, 279.

19. N. Hatanaka, H. Nakaden, Y. Yamamoto, S. Matsuo, T. Fujikawa, and S. Matsusue, Nutrition, 2000, 16, 22.

20. M. Navarro-Alarcon, H. Lopez-Serrana, V. Perez-Valero, and C. Lopez-Martinez, Sci. Total Environ., 1999, 228, 79.

21. J. F. Tyson, N. G. Sundin, C. P. Hanna, and S. A. McIntosh, Spectrochim. Acta, 1997, 52B, 1773.

22. M. M. Gomez, T. Gasparic, M. A. Palacios, and C. Camara, Anal. Chim. Acta, 1998, 374, 241.

23. J. M. G. LaFuente, J. M. Marchante-Gayon, M. L. F. Sanchez, and A. Sanz-Medel, Talanta, 1999, 50, 207.

24. K. L. Yang and S. J. Jiang, Anal. Chim. Acta, 1995, 307, 109.

25. M. A. Quijano, A. M. Gutierrez, M. C. Perez-Conde, and C. Camara, Talanta, 1999, 50, 165.

26. M. L. Gozzo, L. Colacicco, C. Calla, G. Barbaresi, R. Parroni, B. Giardina, and S. Lippa, Clin. Chim. Acta, 1999, $285,53$.

27. C. J. Horng and S. R. Lin, Talanta, 1997, 45, 75.

28. B. Gammelgaard and O. Jons, J. Anal. At. Spectrom., 1999, $14,867$.

29. T. D. B. Lyon, G. S. Fell, R. C. Hutton, and A. N. Eaton, J. Anal. At. Spectrom., 1988, 3, 265.

30. H. Seki, Nippon Eiseigaku Zasshi, 1989, 43, 1149.

31. J. Versieck, L. Vanballenberghe, A. D. Kesel, J. Hoste, B. Wallaeys, J. Vandenhaute, N. Baeck, H. Steyaert, A. R. Byrne, and F. W. Sunderman, Jr., Anal. Chim. Acta, 1988, 204, 63.

32. J. A. Adam, E. Booth, and J. D. H. Strickland, Anal. Chim. Acta, 1952, 6, 462.

33. H. W. Peng and M. S. Kuo, Anal. Sci., 2000, 16, 157.

34. A. J. Bard, R. Parsons, and J. Jordan (ed.), "Standard Potentials in Aqueous Solution", 1985, Marcel Dekker, New York, 265.

35. B. Radziuk and Y. Thomassen, J. Anal. At. Spectrom., 1992, 7, 397.

36. R. D. Ediger, At. Absorpt. Newsl., 1975, 14, 127.

37. J. E. Teague-Nishimura, T. Tominaga, T. Katsura, and K. Matsumoto, Anal. Chem., 1987, 59, 1647.

38. D. L. Styris, L. J. Prell, D. A. Redfield, J. A. Holcombe, D. A. Bass, and V. Majidi, Anal. Chem., 1991, 63, 508. 